\title{
Diurnal Variation in Weight and Rates of Shrink of Range Cows and Calves
}

\section{R.K. HEITSCHMIDT}

\section{Abstract}

Cow-calf pairs were weighed on successive mornings to determine the effects of time on total weight. Early morning weights of mature Hereford/Angus crossbred cows were approximately $2.5 \%$ less than late morning weights in both the spring and summer. Weights of suckling calves were not significantly different between early and late morning. Linear regression analyses indicated drylot shrink weights of cows were primarily a function of length of time of shrink. Rate of weight loss was approximately $1 \%$ every 3 hours after an initial 3 hour loss of 3.5\%. Secondary factors were status of cow (dry or wet), relative humidity (\%), season (spring or summer) and initial cow weight. Shrink rates were slightly greater for wet cows than dry cows; when relative humidity was low; during spring; and for lighter welght cows. Rates of shrink of calves were primarily related to size of calf with calves weighing less than $53 \mathrm{~kg}$ (117 lb) gaining weight and calves weighing more than $53 \mathrm{~kg}$ losing weight.

Differences in liveweight of livestock are often used to evaluate the effect of various experimental treatments on livestock performance. At the Texas Experimental Ranch the magnitude of weight change over time of individual cows and the weaning weight of their calves are the principal parameters utilized to contrast the effects of stocking rate, grazing system and level of winter supplement (Heitschmidt et al. 1982). Because of the number of cattle in each treatment herd, gathering and weighing generally begins in early morning and extends into the early afternoon over a period of 3 days. Thus, weight differences between herds may reflect not only treatment effects but also the effects of the time of day the animals were gathered and weighed.

The first objective of this study was to quantify differences in cow and calf weights as a function of time of day when weighed. The second objective was to examine the rate of drylot shrink of both cows and calves as a function of length of shrink, envi ronmental conditions, initial weight and time of day when the animals were gathered and penned. This objective was established to evaluate the feasibility of gathering herds and weighing after a predetermined period of shrink so as to standardize weights.

\section{Methods}

The study was conducted during the spring and summer of 1979 at the Texas Experimental Ranch located $\left(99^{\circ} 14^{\prime} \mathrm{W}, 33^{\circ} 20^{\prime} \mathrm{N}\right)$ in Throckmorton County in the Northern Rolling Plains. Two of the 3 herds in a 4-pasture deferred rotation system (Merrill 1954) were selected for study. Each herd consisted of 24 Hereford/Angus crossbred cows of similar size and age. Ten of the 48 cows did not calve or had lost their calf prior to the study being initiated. Average date of calving for the 38 calves was mid-December. Both herds were located in pastures approximately $1.0 \mathrm{~km}$ from the weighing facilities.

\footnotetext{
Author is associate professor, Department of Range Science, Texas A\&M University Research and Extension Center, Box 1658, Vernon, 76384.

Report is published with approval of the Director, Texas Agricultural Experiment Station as TA 16425.

Appreciation is expressed to Swen R. Swenson Cattle Co. for providing the cattle and research facilities for this study.

Manuscript received October 31, 1980.
}

Experiment 1 was designed to examine the differences in cow and calf weights as a function of time of morning when the animals were gathered and weighed (Table 1). Experiment 2 was designed to quantify the rate of weight loss during the drylot shrink (Table 2). Both experiments consisted of replicated spring and summer trials run 1 week apart. Weighing of an entire herd generally required approximately 30 minutes. Although time to gather a herd within a pasture varied depending upon herd location, gathering and trailing time averaged approximately 1 hour. Ambient temperature $\left({ }^{\circ} \mathrm{C}\right)$ and relative humidity $(\%)$ were recorded at time of each weighing event. All weights were recorded to the nearest $2.25 \mathrm{~kg}(5.0 \mathrm{lb})$.

Standard analysis of variance procedures were used to analyze the data from Experiment 1 . The replicated $2 \times 3$ factorial designed model considered time of day, season of year, and herds as factors (Snedecor and Cochran 1967). Data from Experiment 2 were analyzed utilizing least squares stepwise linear regression procedures (Draper and Smith 1966). A series of analyses were run with percentage shrink as the dependent va riable. Independent quantitative variables included individual pre-shrunk weights and time weighted averages for temperature $\left({ }^{\circ} \mathrm{C}\right.$ and ${ }^{\circ} \mathrm{F}$ ), relative humidity $(\%)$, and a temperature/relative humidity ratio ${ }^{\circ} \mathrm{C} / \% \mathrm{RH}$ and ${ }^{\circ} \mathrm{F} / \% \mathrm{RH}$ ). Dummy variables of 1 and 0 were used for status of cow (wet or dry), season of trial (spring or summer), and initial time of day that the trial shrink was begun (a.m. or p.m.). Age of calf (days) was also included as an independent variable in the calf weight analyses. The regression procedures added independent variables if they met the $P=0.50$ level of significance for the partial $F$-value. All variables included in the models and discussed in this paper were highly significant $(P<0.01)$ as were the $R^{2}$ values.

\section{Results and Discussion}

\section{Time of Weighing}

The analysis of variance indicated that lactating cows with calves (wet cows) gain a significant $(P<0.01)$ amount of weight during mornings. Early morning weights averaged $457 \mathrm{~kg}$ while late morning weights averaged $468 \mathrm{~kg}$. The analyses also indicated that cows in herd $A$ were significantly $(P<0.05)$ lighter $(459 \mathrm{~kg})$ than cows in herd $B(466 \mathrm{~kg})$ and that the cows weighed significantly $(P<0.01)$ more in the summer $(476 \mathrm{~kg})$ than in the spring $(449 \mathrm{~kg})$. All first order interactions were nonsignificant $(P<0.05)$.

The significant weight increase during the morning was assumed to be the result of increased rumen fill in conjunction with grazing. Taylor (1954) reported that the weight of the contents of the alimentary tract of mature cattle range from $12 \%$ to $22 \%$ of the total liveweight. Thus, differences in level of fill can dramatically affect liveweights. Under range conditions, Hughes and Harker (1950) reported that $600 \mathrm{~kg}$ steers gained weight while grazing at a rate of $11.4 \mathrm{~kg} / \mathrm{hour}$ and lost weight while resting at an average rate near $2.0 \mathrm{~kg} /$ hour. Thus under range conditions, grazing behavior is the major factor altering level of rumen fill at any give time. The reported effects that such factors as quantity and quality of available forage (Hughes 1976), type of grazing system (Taylor 1954), and availability of water (Whiteman et al. 1954) have on level of rumen fill arc directly related to the effect these factors have on 
Table 1. Calendar date, herd, time of weighing (CST), temperature $\left({ }^{\circ} \mathrm{C}\right)$, and relative humidity $(\%)$ at time of weighing and average weights $(\mathrm{kg})$ for Experiment 1.

\begin{tabular}{|c|c|c|c|c|c|c|c|}
\hline \multirow[b]{2}{*}{ Date } & \multirow[b]{2}{*}{ Herd } & \multirow[b]{2}{*}{ Time } & \multirow[b]{2}{*}{${ }^{\circ} \mathrm{C}$} & \multirow[b]{2}{*}{$\% \mathrm{RH}$} & \multicolumn{3}{|c|}{ Weight } \\
\hline & & & & & Wet cows & Calves & Dry cows \\
\hline May 8 & $\begin{array}{l}\mathbf{B} \\
\mathbf{A}\end{array}$ & $\begin{array}{r}7: 00 \\
10: 45\end{array}$ & $\begin{array}{l}20 \\
27\end{array}$ & $\begin{array}{l}96 \\
58\end{array}$ & $\begin{array}{l}440 \\
447\end{array}$ & $\begin{array}{l}150 \\
144\end{array}$ & $\begin{array}{l}475 \\
458\end{array}$ \\
\hline May 9 & $\begin{array}{l}\text { A } \\
\text { B }\end{array}$ & $\begin{array}{r}7: 45 \\
10: 15\end{array}$ & $\begin{array}{l}21 \\
24\end{array}$ & $\begin{array}{l}80 \\
64\end{array}$ & $\begin{array}{l}432 \\
451\end{array}$ & $\begin{array}{l}143 \\
151\end{array}$ & $\begin{array}{l}447 \\
480\end{array}$ \\
\hline May 15 & $\begin{array}{l}\text { A } \\
\text { B }\end{array}$ & $\begin{array}{r}6: 15 \\
10: 15\end{array}$ & $\begin{array}{l}12 \\
24\end{array}$ & $\begin{array}{l}90 \\
34\end{array}$ & $\begin{array}{l}445 \\
464\end{array}$ & $\begin{array}{l}151 \\
161\end{array}$ & $\begin{array}{l}462 \\
492\end{array}$ \\
\hline May 16 & $\begin{array}{l}\text { B } \\
\text { A }\end{array}$ & $\begin{array}{r}6: 15 \\
10: 00\end{array}$ & $\begin{array}{l}11 \\
22\end{array}$ & $\begin{array}{c}100 \\
40\end{array}$ & $\begin{array}{l}456 \\
456\end{array}$ & $\begin{array}{l}162 \\
153\end{array}$ & $\begin{array}{l}492 \\
470\end{array}$ \\
\hline July 23 & $\begin{array}{l}\text { A } \\
\text { B }\end{array}$ & $\begin{array}{r}7: 30 \\
10: 30\end{array}$ & $\begin{array}{l}23 \\
35\end{array}$ & $\begin{array}{l}98 \\
30\end{array}$ & $\begin{array}{l}466 \\
484\end{array}$ & $\begin{array}{l}215 \\
230\end{array}$ & $\begin{array}{l}503 \\
532\end{array}$ \\
\hline July 24 & $\begin{array}{l}\text { B } \\
\text { A }\end{array}$ & $\begin{array}{r}7: 30 \\
10: 30\end{array}$ & $\begin{array}{l}23 \\
30\end{array}$ & $\begin{array}{l}85 \\
45\end{array}$ & $\begin{array}{l}478 \\
479\end{array}$ & $\begin{array}{l}228 \\
217\end{array}$ & $\begin{array}{l}527 \\
508\end{array}$ \\
\hline July 30 & $\begin{array}{l}\text { B } \\
\text { A }\end{array}$ & $\begin{array}{r}7: 30 \\
10: 30\end{array}$ & $\begin{array}{l}26 \\
32\end{array}$ & $\begin{array}{l}72 \\
72\end{array}$ & $\begin{array}{l}476 \\
484\end{array}$ & $\begin{array}{l}233 \\
226\end{array}$ & $\begin{array}{l}532 \\
515\end{array}$ \\
\hline July 31 & $\begin{array}{l}\mathbf{A} \\
\mathbf{B}\end{array}$ & $\begin{array}{r}7: 30 \\
10: 30\end{array}$ & $\begin{array}{l}22 \\
23\end{array}$ & $\begin{array}{l}100 \\
85\end{array}$ & $\begin{array}{l}461 \\
477\end{array}$ & $\begin{array}{l}223 \\
232\end{array}$ & $\begin{array}{l}501 \\
527\end{array}$ \\
\hline
\end{tabular}

grazing behavior (Hughes and Harker 1950).

Results from the last trial of the study (July 30 and 31 ) emphasized the effect that environmental factors can have on the weight of a grazing animal if grazing behavior is altered such that level of fill is affected. July 30 was a clear, warm summer day and cow weights were very similar to those for the same time of day on July 23 and 24 (Table 1). But the weights on July 31 were well below those expected presumably because rumen fills were less than expected. Apparently the cows did not graze during the morning of July 31 , a change in grazing behavior which presumably was related to the rain (Table 1). Excluding the weights from the last trial, percentage differences in wet cow weights between early and late morning ranged from a maximum of $3.4 \%$ for herd A on May 8 and 9 to a minimum of $1.3 \%$ for herd B on July 23 and 24 . The average gain during mornings for all the trials was $2.5 \%$

Although the weight gain of dry cows from early to late morning was statistically nonsignificant, trends were similar to those established for wet cows although of reduced magnitude. Averaged across all trials, weights increased during mornings $1.1 \%$ ranging from an increase of $2.8 \%$ in herd A during the last trial to a decline of $-0.9 \%$ in herd $B$ on the same date. These extremes during the last trial were likely related to the weather conditions as discussed earlier. Excluding these data, morning weight gains ranged from zero to $2.4 \%$ with an average gain of $1.0 \%$. The reduced magnitude of morning weight flux of the dry cows in contrast to the wet cows was presumed to be related to two factors; rumen fill and milk secretion. Allen (1946) reported that weights of lactating animals fluctuate more within a day than nonlactating animals because of the relatively greater quantities of food and water that a re consumed by lactating animals, as well as the loss of weight resulting from milk secretion.

Analyses of the calf weights indicated no significant $(P<0.05)$ differences between early and late morning weights or between herds although calves were significantly $(R<0.01)$ heavier in the summer than the spring. All first order interactions were nonsignificant $(R<0.05)$. The absence of a significant treatment by season interaction indicated that treatment effects did not become significantly more pronounced as the calves grew during the spring and summer. However, gains during the morning averaged $0.6 \%$ in May, ranging from $-0.6 \%$ to $1.7 \%$, while in July gains averaged $0.9 \%$ ranging from $-0.2 \%$ to $1.5 \%$. Although statistically nonsignificant, this $0.3 \%$ average increase indicated that as the calves grew, diurnal variation in liveweights was becoming more pronounced. This would be expected since Kirton and Paterson (1971) reported that the weight of the stomach contents of 3-day-old calves was only $4 \%$ of total liveweight as opposed to the $12 \%$ to $22 \%$ reported by Taylor (1954) for mature cattle.

From these analyses it was concluded that range cows generally gain weight from early to late morning if permitted to graze but the effect that the time of day has on the weight of suckling calves is minimal.

\section{Rate of Shrink}

The stepwise linear regression selected time in drylot $\left(x_{1}\right)$ as the best single variable for predicting the percent shrink of the cows (Table 3). The +0.35 coefficient indicated rate of shrink averaged approximately $1 \%$ every 3 hours after an initial 3 -hour shrink of approximately $3.5 \%$.

When percent shrink was plotted against hours in drylot, an obvious curvilinear relationship was apparent (Fig. 1). When the data were fit by least square regression procedures to the allometric function of $\mathrm{y}=\mathrm{ax}^{\mathrm{b}}$, the $R^{\mathrm{b}}$ value increased to 0.69 . This increase in the $R^{2}$ value was attributed primarily to a better fit of the data when shrinks were less than 7 hours. For example, at 3 hours predicted shrink from the equation $\mathrm{y}=2.43+0.35 \mathrm{X}_{1}$ was $3.48 \%$ as compared to a predicted value of $2.53 \%$ from the allometric function of $\mathrm{y}=0.16 \mathrm{X}_{1}^{0.70}$. The herd means for percent shrink from the field

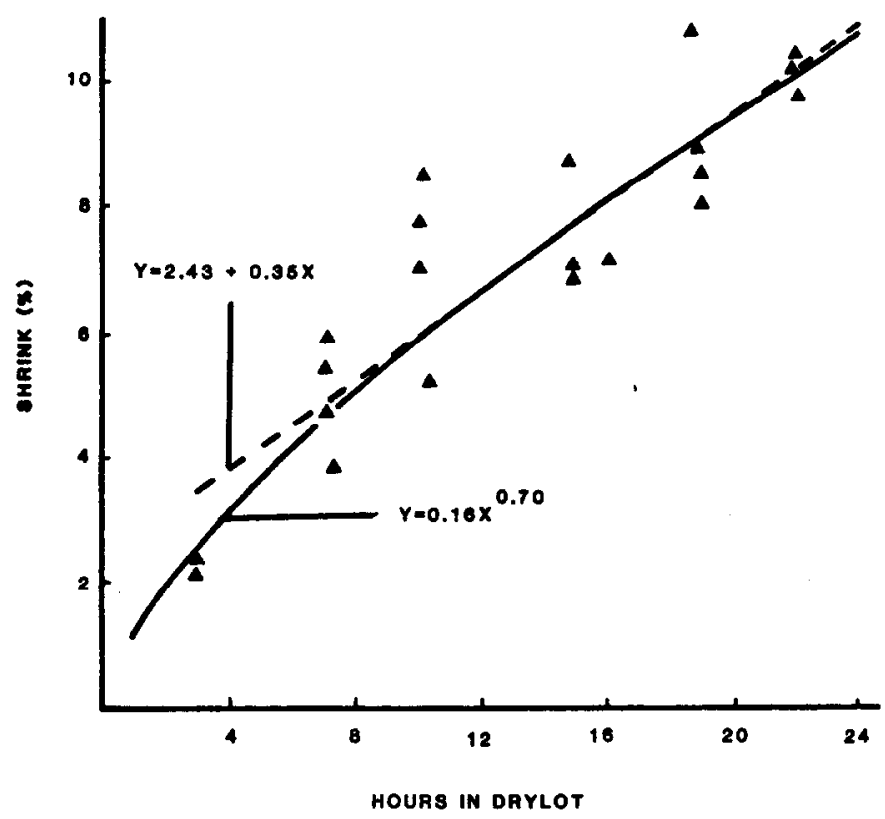

Fig. 1. Percent loss of weight $(Y)$ of range cows as a function of hours in drylot $(X)$ at the Texas Experimental Ranch. 
Table 2. Calendar date, herd, time of weighing (CST), temperature $\left({ }^{\circ} \mathrm{C}\right)$ and relative humidity $(\%)$ at time of weighing and average weights $(\mathrm{kg})$ for Experiment 2.

\begin{tabular}{|c|c|c|c|c|c|c|c|}
\hline \multirow[b]{2}{*}{ Date } & \multirow[b]{2}{*}{ Herd } & \multirow[b]{2}{*}{ Time } & \multirow[b]{2}{*}{${ }^{\circ} \mathrm{C}$} & \multirow[b]{2}{*}{$\%$ RH } & \multicolumn{3}{|c|}{ Weights } \\
\hline & & & & & Wet cows & Calves & Dry cows \\
\hline April 25 & A & $\begin{array}{l}7: 00 \mathrm{am} \\
2: 00 \mathrm{pm} \\
5: 15 \mathrm{pm}\end{array}$ & $\begin{array}{l}18 \\
31 \\
24\end{array}$ & $\begin{array}{l}82 \\
20 \\
32\end{array}$ & $\begin{array}{l}425 \\
399 \\
388\end{array}$ & $\begin{array}{l}130 \\
126 \\
125\end{array}$ & $\begin{array}{l}443 \\
421 \\
415\end{array}$ \\
\hline $\begin{array}{l}\text { April } 25 \\
\text { April } 26\end{array}$ & B & $\begin{array}{c}4: 40 \mathrm{pm} \\
7: 25 \mathrm{am} \\
11: 20 \mathrm{am}\end{array}$ & $\begin{array}{l}18 \\
10 \\
18\end{array}$ & $\begin{array}{l}82 \\
64 \\
42\end{array}$ & $\begin{array}{l}440 \\
399 \\
388\end{array}$ & $\begin{array}{l}137 \\
135 \\
133\end{array}$ & $\begin{array}{l}481 \\
449 \\
441\end{array}$ \\
\hline May 3 & B & $\begin{array}{l}6: 45 \mathrm{am} \\
1: 55 \mathrm{pm} \\
4: 45 \mathrm{pm}\end{array}$ & $\begin{array}{l}16 \\
12 \\
11\end{array}$ & $\begin{array}{r}96 \\
100 \\
100\end{array}$ & $\begin{array}{l}434 \\
416 \\
409\end{array}$ & $\begin{array}{l}145 \\
141 \\
141\end{array}$ & $\begin{array}{l}473 \\
459 \\
455\end{array}$ \\
\hline $\begin{array}{l}\text { May } 3 \\
\text { May } 4\end{array}$ & A & $\begin{array}{c}3: 45 \mathrm{pm} \\
7: 45 \mathrm{am} \\
10: 30 \mathrm{am} \\
2: 00 \mathrm{pm}\end{array}$ & $\begin{array}{r}11 \\
7 \\
11 \\
11\end{array}$ & $\begin{array}{r}100 \\
90 \\
70 \\
58\end{array}$ & $\begin{array}{l}441 \\
409 \\
401 \\
395\end{array}$ & $\begin{array}{l}140 \\
138 \\
137 \\
136\end{array}$ & $\begin{array}{l}458 \\
428 \\
422 \\
417\end{array}$ \\
\hline July 9 & & $\begin{array}{l}6: 00 \mathrm{am} \\
9: 00 \mathrm{am} \\
1: 00 \mathrm{am} \\
4: 00 \mathrm{pm}\end{array}$ & $\begin{array}{l}21 \\
32 \\
37 \\
37\end{array}$ & $\begin{array}{l}90 \\
40 \\
26 \\
26\end{array}$ & $\begin{array}{l}466 \\
455 \\
440 \\
430\end{array}$ & $\begin{array}{l}203 \\
200 \\
196 \\
193\end{array}$ & $\begin{array}{l}502 \\
494 \\
479 \\
468\end{array}$ \\
\hline $\begin{array}{l}\text { July } 9 \\
\text { July } 10\end{array}$ & B & $\begin{array}{c}\text { 3:30 } \mathrm{pm} \\
6: 30 \mathrm{am} \\
10: 30 \mathrm{am} \\
1: 30 \mathrm{pm}\end{array}$ & $\begin{array}{l}37 \\
20 \\
28 \\
22\end{array}$ & $\begin{array}{l}26 \\
96 \\
50 \\
78\end{array}$ & $\begin{array}{l}487 \\
451 \\
443 \\
434\end{array}$ & $\begin{array}{l}217 \\
210 \\
206 \\
204\end{array}$ & $\begin{array}{l}527 \\
502 \\
492 \\
486\end{array}$ \\
\hline July 16 & B & $\begin{array}{l}\text { 6:00 am } \\
\text { 9:00 am } \\
2: 00 \mathrm{pm} \\
\text { 4:00 pm }\end{array}$ & $\begin{array}{l}24 \\
29 \\
35 \\
37\end{array}$ & $\begin{array}{l}74 \\
58 \\
28 \\
25\end{array}$ & $\begin{array}{l}469 \\
457 \\
445 \\
434\end{array}$ & $\begin{array}{l}220 \\
216 \\
213 \\
210\end{array}$ & $\begin{array}{l}521 \\
511 \\
502 \\
492\end{array}$ \\
\hline $\begin{array}{l}\text { July } 16 \\
\text { July } 17\end{array}$ & $\mathbf{A}$ & $\begin{array}{c}3: 30 \mathrm{pm} \\
6: 30 \mathrm{am} \\
10: 30 \mathrm{am} \\
1: 30 \mathrm{pm}\end{array}$ & $\begin{array}{l}37 \\
22 \\
22 \\
24\end{array}$ & $\begin{array}{r}25 \\
100 \\
100 \\
72\end{array}$ & $\begin{array}{l}477 \\
442 \\
437 \\
430\end{array}$ & $\begin{array}{l}211 \\
203 \\
202 \\
200\end{array}$ & $\begin{array}{l}510 \\
485 \\
479 \\
470\end{array}$ \\
\hline
\end{tabular}

data after 3 hours were $2.2 \%$ and $2.4 \%$ (Fig. 1). However, for the period from 7 to 22 hours both the linear and the allometric equations predicted percent shrink equally well. For 10 and 20 hours in drylot, predicted shrinks were $5.93 \%$ and $9.43 \%$ from the linear equation and $5.88 \%$ and $9.55 \%$ from the allometric equation. Thus, it was concluded that the linear regression adequately describe the relationship between percent shrink of the cows and time in drylot for periods of shrink between 3 and 22 hours although the allometric function described the relationship slightly better. This was a desirable conclusion since the use of linear regression procedures simplified the biological interpretation of the data. Furthermore, the level of mathematics necessary to apply the least square equations to actual field situations is considerably less when relationships are described as linear functions rather than allometric.

The rates of shrink for the cows in this study agreed rather closely with previous studies. Taylor (1954) reported drylot shrinks averaging $5.6 \%$ for 12 hours and $8.2 \%$ for 24 hours for mature steers that initially weighed $535 \mathrm{~kg}$. This is in comparison to predicted shrinks for the cows in this study of $6.6 \%$ for 12 hours and $10.8 \%$ for 24 hours. In a series of trials Whiteman et al. (1954)

Table 3. Stepwise linear regression coefficients selected to predict weight loss of drylotted range cows at the Texas Experimental Ranch where $y=$ shrink (\%); $X_{1}=$ time in drylot (hours); $X_{2}=$ status of cow $(0=$ dry, $1=$ wet); $X_{3}=$ relative humidity $(\%) ; X_{4}=$ season of year $(0=$ spring, $1=$ summer); and $\mathrm{X}_{5}=$ initial weight of cow (kg). All associated $R^{2}$ values were significant at $P<0.01$ (d.f. $=503$ ).

\begin{tabular}{lc} 
Regression coefficients & $R^{2}$ \\
\hline$y=2.45+0.35 X_{1}$ & 0.60 \\
$y=0.98+0.34 X_{1}+1.85 X_{2}$ & 0.67 \\
$y=3.04+0.38 X_{1}+1.82 X_{2}-0.04 X^{3}$ & 0.72 \\
$y=5.86+0.39 X_{1}+1.80 X_{2}-0.06 X_{3}-1.79 X_{4}$ & 0.79 \\
$y=9.11+0.40 X_{1}+1.53 X_{2}-0.06 X_{3}-1.45 X_{4} \cdot 0.01 X_{5}$ & 0.80 \\
\hline
\end{tabular}

reported overnight shrink rates ranging from $2.3 \%$ to $6.1 \%$ for growing steers that initially weighed about $415 \mathrm{~kg}$. Differences in rate of shrink were related to preshrunk differences in level and type of fill. Hughes (1976) in a summarization of the findings of Whiteman et al. (1954) and other similar types of research conducted at the Grassland Research Station (1953), reported 12-hour shrinks ranging from approximately $18 \mathrm{~kg}$ to $40 \mathrm{~kg}$ for steers ranging in weight from 464 to $577 \mathrm{~kg}$. Twenty-four hour shrinks ranged from 34 to $62 \mathrm{~kg}$. Assuming an average pre-shrunk weight of $520 \mathrm{~kg}$, the average 12-hour shrink was $5.6 \%$ and the average for 24 hours was $9.2 \%$. Likewise, Wythes et al. (1980) reported 12 -and 24-hour shrinks of $5.9 \%$ and $7.4 \%$ for steers weighing an average of $296 \mathrm{~kg}$.

The second variable selected in the analyses was status (dry or wet) of cow $\left(X_{2}\right)$. The +1.85 coefficient (Table 3 ) indicated that wet cows lost $1.85 \%$ more weight than dry cows, regardless of time of shrink. Predicted shrinks for dry cows at 12 and 24 hours were $5.2 \%$ and $9.4 \%$. Adding the $1.85 \%$, predicted shrinks for the wet cows were $7.0 \%$ and $11.2 \%$ for 12 and 24 hours, respectively. The increased rate of shrink for the wet cows was most likely because their preshrink level of fill was greater than that of the dry cows and they sustained a greater loss of weight because of the secretion of milk (Allen 1946).

The third variable selected was relative humidity $\left(\mathrm{X}_{3}\right)$ (Table 3 ). The -0.04 coefficient indicated that rate of shrink was reduced slightly as relative humidity increased. A biological explanation as to why shrink rates were reduced in conjunction with an increase in relative humidity is at best speculative since the selection of relative humidity over temperature was not expected. Paine et al. (1977) reported that increasing temperature reduced average daily gains of cattle in feedlots more than initial weight, wind speed, precipitation or relative humidity. Furthermore, it has been shown that rate of respiration of beef cattle is closely correlated with body temperature (Paine and Butchbaker 1971). Since cattle rely on respiration as the primary method of heat release (Paine 1976), one would 
expect weight losses to be more closely related to temperature than relative humidity. However, because of the close relationship between relative humidity and temperature during the trials $(r=$ $-0.85, P<0.01$ ), temperature apparently became relatively unimportant once relative humidity entered the equations.

The fourth variable selected was season of year $\left(\mathrm{X}_{4}\right)$ that the trial was run (Table 3). The -1.79 coefficient indicated that rate of shrink was less during summer than spring. However, because of differences in environmental conditions between spring and summer this coefficient only slightly modified the predicted shrink.

The final variable selected was the initial preshrunk weight of the cow $\left(\mathrm{X}_{5}\right)$. Although the -0.01 coefficient (Table 3 ) indicated that rate of shrink decreased slightly as initial weight increased, it is doubtful that this phenomenon was related to level of rumen fill. If it were assumed that the heavier weight cows were heavier because of greater levels of fill, then these results would be in conflict with previous findings which have shown that the greater the preshrink fill the faster the shrink (Hughes 1976). Rather, it was assumed that the -0.01 coefficient was most likely describing the interaction effect of several interdependent factors. For example, it was assumed that it reflected at least in part the slightly accelerated shrink rate that had already been established for the lighter weight wet cows as compared to the heavier weight dry cows. Also, since relative humidities were lower and temperatures were higher during the daytime shrinks than the nighttime shrinks (Table 2), shrink rates during the day would be expected to be slightly greater than those during the night. Again this would suggest that lighter cows shrink faster since the initial preshrink weights for the cows when gathered in early morning averaged approximately $13 \mathrm{~kg}$ less than when the cows were gathered in the afternoon for the overnight shrink.

Three independent variables did not satisfy the $P=0.50$ significance level required for inclusion. These variables were ambient air temperature, the relative humidity/temperature index and the time of day that the trial was begun. In each instance the lack of total independence from other factors already included in the model most likely diminished the significance of any of these factors.

From these analyses it was apparent that rate of shrink of the cows was primarily a function of time in drylot. This was evidenced by both the selection of time as the first independent variable and the relatively small increases in the $R^{2}$ value that occurred with the addition of each new variable.

Rate of shrink (y) of the suckling calves was primarily a function of three variables: initial weight of calf $\left(X_{1}\right)$; time in drylot $\left(X_{2}\right)$; and time of day $\left(X_{3}\right)$ trial was begun (Table 4). The -1.60 intercept coefficient, in conjunction with the +0.03 coefficient for the preshrink weight $\left(X_{1}\right)$, suggested that no shrink was predicted until calves weighed approximately $53 \mathrm{~kg}$. The +0.03 coefficient suggested rate of shrink would increase slightly as initial weight of calf increased. Presumably, this slight acceleration was related to the relative increase that gut fill may have on total liveweight as an animal grows. Also, drylotting young calves does not deprive the calves of their primary food source since they probably continue to receive a near normal portion of milk.

Time in drylot $\left(\mathrm{X}_{2}\right)$ was selected as the second best variable for predicting shrink of calves (Table 4 ). The +0.10 coefficient suggested a slightly greater shrink occurred as time in drylot was extended. The final variable selected was time of day when the

\begin{tabular}{|c|c|}
\hline Regression coefficients & $R^{2}$ \\
\hline $\begin{array}{l}y=-1.60+0.03 x_{1} \\
y=-3.05+0.03 x_{1}+0.10 x_{2} \\
y=-4.14+0.03 x_{1}+0.26 x_{2}-2.45 x_{3}\end{array}$ & $\begin{array}{l}0.28 \\
0.35 \\
0.41\end{array}$ \\
\hline
\end{tabular}

shrink was begun $\left(\mathrm{X}_{3}\right)$. The -2.45 indicated rates of shrink declined during nights in contrast to daytime shrinks. This was most likely related to the lower temperatures and higher relative humidities experienced during nights relative to days. No other variables met the $P=0.50$ level of significance for inclusion in the model.

It was concluded from these analyses that rate of shrink of the suckling calves was minimal if the calves were left with their mother cow. This was particularly true for smaller calves. For example, after 10 hours predicted shrink for a $100 \mathrm{~kg}$ calf was only $0.5 \%$. However, as the calves reached weaning weight rates of shrink began to reflect rates similar to those of more mature cattle. For example, after 10 hours predicted shrink for a $300 \mathrm{~kg}$ calf was $5.7 \%$. This compares to a predicted shrink of $5.9 \%$ for a mature wet cow.

\section{Conclusions}

These data suggest that if at all possible, cow weights obtained to contrast grazing treatment effects should be collected at a similar time of day under similar environmental conditions. These data also suggest that a period of drylot shrink prior to weighing will not standardize range cow weights unless length of shrink and environmental conditions during the shrink are similar. It is assumed, in contrast to the findings of Whiteman et al. (1954), that trailing increases rates of shrink. Thus, it is recommended that under range conditions, those cows nearest the weighing facilities be weighed first and those farthest from the facilities be weighed last.

These data indicate that the magnitude of both the diurnal weight fluctuation and the rate of drylot shrink of suckling calves is a function of size of calf in that the lighter the calf the less diurnal weight fluctuation and rate of drylot shrink. But since calves at weaning often weigh $300 \mathrm{~kg}$, every precaution should be taken to obtain accurate weights especially since $10 \mathrm{~kg}$ differences in calf weaning weights is sufficient economic justifications for advocating certain grazing management practices. Thus, it is concluded that the same order of weighing utilized to weigh the cow herds should be followed when weighing the calves.

\section{Literature Cited}

Allen, N.N. 1946. Variations in the live weight of dairy cattle. Bull. Vermont Agr. Exp. Sta. No. 534.12 p.

Draper, N.R., and H. Smith. 1966. Applied regression analysis. John Wiley and Sons, Inc. New York. 407 p.

Grassland Research Station. 1953. Studies of variability in liveweight determinations of bullocks and sheep. Exp. Prog., Grassld. Res. Sta. Hurley, Eng. 6:62-64.

Heitschmidt, R.K., M.M. Kothmann, and W.J. Rawlins. 1982. Cow-calf response to stocking rates, grazing systems and winter supplementation at the Texas Experimental Ranch. J. Range Manage. 35:204-210.

Hughes, J.G. 1976. Short-term variation in animal live weight and reduction of its effect on weighing. Anim. Breed. Abst. 44:111-118.

Hughes, G.P., and K.W. Harker. 1950. The technique of weighing bullocks on summer grass. J. Agr. Res. 24:271-277.

Kirton, A.H., and D.J. Paterson. 1971. Effect of pre-slaughter starvation on weight-loss in cattle. Proc. New Zealand Soc. Anim. Prod. 31:42.

Merrill, Leo B. 1954. A variation of deferred rotation grazing for use under southwest range conditions. J. Range Manage. 7:152-154.

Paine, Myron D. 1976. Thermoregulation in beef cattle. ASAE Paper No. 76-5007, Amer. Soc. Agr. Eng., Lincoln, Neb.

Paine, Myron D., and A.F. Butchbaker. 1971. Dynamic modeling of the thermal state in beef animals. ASAE Paper No. 71-596, Amer. Soc. Agr. Eng., St. Joseph, MO.

Paine, Myron, D., G.W.A. Mahoney, and A.F. Butchbaker. 1977. Feedlot efficiency as a function of climate. Tran. Amer. Soc. Agr. Eng. 20:314318.

Snedecor, G.W. and W.C. Cochran. 1967. Statistical methods. 6th ed. Lowa St. Univ. Pres, Ames. 593 p.

Tayler, J.C. 1954. Technique for weighing the grazing animal. Pro. Brit. Soc. Anim. Prod., p. 3-16.

Whiteman, Joe V., P.F. Ioggins, Doyle Chambers, L.S. Pope, and D.F. Stephens. 1954. Some sources of error in weighing steers off grass. J. Anim. Sci, 13:832-842.

Wythes, J.R., W.R. Shorthose, P.J. Schmidt, and C.B. Davis. 1980. Effects of various rehydration procedures after a long journey on liveweight, carcasses and muscle properties of cattle. Aust. J. Agr. Res. 31:849-855. 